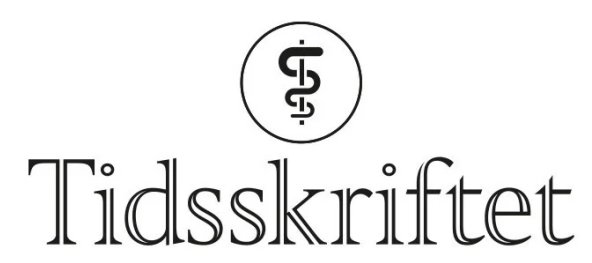

DEN NORSKE LEGEFORENING

\title{
Komponentanalyser i allergidiagnostikk
}

FRA LABORATORIET

\section{INGRID HOKSTAD}

ihokstad@gmail.com

Ingrid Hokstad er lege i spesialisering ved Avdeling for blodbank og medisinsk biokjemi ved Sykehuset Innlandet.

Forfatteren har fylt ut ICMJE-skjemaet og oppgir ingen interessekonflikter.

\section{Hvordan kan komponentanalyser hjelpe klinikere til å stille mer presise allergidiagnoser og dermed gi bedre tilpassede råd til pasienter med mistenkt allergi?}

Allergi er en immunologisk betinget hypersensitivitetsreaksjon, en overfølsomhet mot et allergen som folk flest tåler. Allergier kan være både IgE-medierte og ikke-IgE-medierte, og i denne teksten er det IgE-medierte allergier som omtales.

IgE-mediert allergi kan påvises ved hjelp av prikktest eller ved direkte påvisning av IgE, oftest i serum. Gullstandarden for en sikker allergidiagnose er en provokasjonstest, helst dobbeltblind og placebokontrollert. De sistnevnte testene er imidlertid ressurskrevende og ikke uten risiko, og reserveres for utvalgte pasienter der sikker diagnose er viktig, for eksempel ved alvorlig anafylaksi og når man ønsker å unngå å fjerne viktige matvarer fra barns kost unødvendig.

\section{Epitoper fra ulike allergenkilder}

For at en IgE-mediert allergisk reaksjon skal oppstå, må et IgE-antistoff gjenkjenne en epitop på et allergen, vanligvis et protein. Et allergen kan inneholde mange slike epitoper, hvorav noen er svært spesifikke for allergenkilden de stammer fra, mens andre ligner på epitoper fra andre allergenkilder. Denne homologien mellom epitoper fra ulike allergenkilder kan gi opphav til kryssreaktivitet: For eksempel inneholder mange allergener fra planteriket en gruppe proteiner kalt PR-10 (patogeneserelaterte proteiner 10). I bjørk kalles PR-10-proteinet Bet v 1, i soya Gly m 4, i hasselnøtt Cor a 1 og i peanøtt Ara h 8. En person som har blitt sensibilisert mot Bet v 1 i bjørk - og følgelig danner IgE ved eksponering for bjørkepollen - kan også danne IgE mot peanøtter, fordi peanøtten inneholder proteinet Ara h 8, som er nærmest identisk med det bjørkeproteinet personen er sensibilisert mot. Personen vil da typisk kunne få lokale symptomer i munn og svelg ved 
inntak av peanøtter, selv om han eller hun ikke har en "genuin peanøttallergi». I slike tilfeller kan komponentanalyser være nyttige for å kartlegge hvilke epitoper man er sensibilisert mot. Man tester da om pasienten produserer IgE mot en spesifikk epitop, og ikke bare mot et «helt allergen». Da ulike epitoper og proteiner er forbundet med ulik risiko for alvorlig reaksjon, kan man dermed i større grad si noe om sannsynligheten for alvorlige allergiske reaksjoner ved eksponering for gitte allergenkilder.

\section{IgE-tester og klinisk allergi}

At man er sensibilisert mot et allergen, er ikke ensbetydende med at man har en klinisk allergi. Man kan nemlig godt produsere spesifikt IgE mot et allergen (altså være sensibilisert), men likevel ikke ha symptomer når man eksponeres for allergenkilden. Man kan også ha en reell IgE-mediert allergi uten at det slår ut på IgE-tester, fordi visse deler av et protein kan mangle eller være underrepresentert i et testekstrakt (1). I I slike tilfeller kan man få et negativt IgE-resultat til tross for klinisk allergi, fordi pasienten reagerer på en del av allergenet som ikke er godt nok representert i ekstraktet. Et eksempel er hveteallergenet Tri a 19 ( $\omega$-5-gliadin), som kan gi opphav til blant annet anstrengelsesutløst anafylaksi. Noen av disse pasientene kan ha negativt resultat for IgE mot hvete, og det vil derfor være nødvendig for laboratoriet å vite om man har en spesifikk mistanke om hveteallergi, slik at riktige komponentanalyser eventuelt kan legges til rekvisisjonen. Rekvirering av spesifikke IgE-analyser er altså meningsløst med mindre man har en klinisk mistanke, og en god anamnese er følgelig svært viktig i allergidiagnostikk. En IgE-test kan bare styrke eller svekke sannsynligheten for IgE-mediert patologi, og ikke gi noen absolutt bekreftelse eller avkreftelse av allergi som årsak til symptomer.

\section{Rekvirering av komponentanalyser}

Komponentanalyser er dyre tester og sjelden nødvendig i standard allergidiagnostikk. Indikasjoner for rekvirering er hovedsakelig å finne ut om en pasient egner seg for behandling med spesifikk immunterapi, og å identifisere primærsensibiliserende allergen ved alvorlige systemiske allergiske reaksjoner (anafylaksi). Komponentanalyser kan også ha sin plass ved et betydelig antall kryssreaksjoner, dersom resultatene vil ha klinisk konsekvens for pasienten. I praksis er det gjerne laboratorieleger som rekvirerer disse analysene, basert på kliniske opplysninger og ønsker fra rekvirenten. Noen klinikere har også adgang til å rekvirere slike analyser direkte.

Allergologi er et fagfelt i rask utvikling, der stadig identifisering og karakterisering av nye allergener gir mulighet for mer presis diagnostikk og målrettet behandling. Det kan være utfordrende å holde seg oppdatert for klinikere som ikke har allergi som sitt hovedfelt, men ved tvil om hvilke prøver som skal rekvireres, kan laboratorielege være behjelpelig. I kompliserte tilfeller kan henvisning til allergologisk vurdering ved et av de regionale sentrene for astma, allergi og overfølsomhet (RAAO) være aktuelt. I tillegg finnes det per nå rundt hundre spesialister med godkjenning innen kompetanseområdet allergologi, majoriteten av dem pediatere og øre-nese-hals-leger.

Leger som ønsker å lese mer, kan søke opp «EAACI Molecular Allergology User's Guide» fra den europeiske allergiorganisasjonen EAACI, og på allergen.org finner man oversikt over alle identifiserte komponenter og allergener anerkjent av Verdens helseorganisasjon.

1. Kleine-Tebbe J, Jakob T. Molecular allergy diagnostics using IgE singleplex determinations: methodological and practical considerations for use in clinical routine: Part 18 of the Series Molecular Allergology. Allergo J Int 2015; 24: 185-97. [PubMed][CrossRef] 
Publisert: 22. oktober 2021. Tidsskr Nor Legeforen. DOI: 10.4045/tidsskr.21.06o8

(C) Tidsskrift for Den norske legeforening 2023. Lastet ned fra tidsskriftet.no 26. april 2023. 